\title{
Adsorption of Triclocarban on Pristine and Irradiated MWCNTs in Aqueous Solutions
}

\author{
ION ION ${ }^{1}$, RALUCA MADALINA SENIN², GEORGETA RAMONA IVAN²*, SANDA MARIA DONCEA², MICHAEL PATRICK HENNING ${ }^{3}$, \\ IRINA POLITOWSKI ${ }^{3}$, ALINA CATRINEL ION ${ }^{1 *}$ \\ 'Politehnica University of Bucharest, Faculty of Applied Chemistry and Material Science, Department of Analytical Chemistry \\ and Instrumental Analysis,1 Polizu Str., 011061, Bucharest, Romania \\ ${ }^{2}$ National Research \& Development Institute for Chemistry and Petrochemistry ICECHIM, Department of Analysis, Tests, and \\ Testing, 202 Splaiul Independentei, 060021 Bucharest, Romania \\ 3Department of Biology, RWTH Aachen University, Templegraben 55, 52062, Aachen, Germany
}

The adsorption of triclocarban was investigated on pristine and irradiated MWCNTs, at differenttemperatures, in aqueous synthetic samples at different $\mathrm{pH}$ values and for different concentrations of humic acid (HA) from natural organic matter. Commonly used models of the adsorption isotherms, Freundlich and Langmuir were selected to fit the experimental data. The effects of TCC concentration, of the temperature and of the concentration of humic acid from natural organic matter were tested to study the impactof the environmental conditions over the sorption process.

Keywords: triclocarban, MWCNTs, sorption, irradiation

Triclocarban (TCC) is widely used as disinfectant in cosmetic industry, being an ingredient in several detergents [1]. Its large consumption led to is presence in the environment, because it is not completely removed by wastewater treatment [2]. TCC was detected not only in wastewaters, but in natural surface and groundwaters, in small concentrations, of $\mu \mathrm{g} / \mathrm{L}$ [3]. This organic contaminant was recently considered a new type of endocrine disruptor which might modify the transcription of genes [4] and bioaccumulates in wetlands [5] and in algae [6]. It can be found in wastewaters from cosmetics and detergents at concentrations between $0.4-50 \mu \mathrm{g} / \mathrm{L}[7,8]$.As an endocrine disruptor, its presence in the environment might have important negative effects over humans and animals [9, 10].

Triclocarban, 3,4,4'-trichlorocarbanilide, $\mathrm{C}_{13} \mathrm{H}_{9} \mathrm{C}_{13} \mathrm{~N}_{2} \mathrm{O}$ is an aromatic compound, a trichlorinated derivative of urea (fig. 1) [11]. Besides its utilizations in cosmetic industry, it is also added in drugs for the treatment of micosis [12]. Its properties are presented in table 1 [13].<smiles>O=C(Nc1ccc(Cl)cc1)Nc1ccc(Cl)c(Cl)c1</smiles>

Fig.1 Chemical structure of triclocarban (TCC)

The literature presents contradictory data concerning the values of the water solubility of TCC and of its octanolwater partitioning coefficient (Kow). The values of TCC solubility are $0.11 \mathrm{mg} / \mathrm{L}[14]$, or between $0.65-1.55 \mathrm{mg} / \mathrm{L}$ [15]. Its log Kow values range between 4.2 and $6.0[6,16]$.
Despite the increased use of TCC as an antimicrobial care product, the wastewater treatments remove it by sludge accumulation [17] not completely [18]. Studies developed till the moment in the literature referring to its sludge accumulation and the potentially occuring health effects were not found. The USEPA mentioned TCC as high priority chemical for risk management activities and requested increased experimental distribution and exposure data from the academic part, companies or voluntary research [19].

In the lastyears, carbon nanomaterials began to be used in remediation environmental problems, based on the progress of nanoscience and nanotechnology achievements [20-22]. Many types of eco-friendly nanomaterials, diversified by functionalization are now available for applications in decontamination of ground water, surface water, drinking water and wastewater, too $[23,24]$.

Multi-walledcarbon nanotubes (MWCNTs) have been tested as sorbents and proved that they can efficiently remove organic and inorganic contaminants from several types of water [25]. Their large specific surface area and their aromatic structure facilitate the $\pi$ - $\pi$ electron coupling interaction with other aromatic organic structures $[26,67]$. The introduction of oxygen containing groups on the surface of MWCNTs influences their aggregation, which reduces in aqueous, or in organic solvents [28]. It is possible that by irradiation (mimicking the weathering in natural aqueous matrices) of the MWCNTs, oxygen-containing functional groups to be attached at the surface, modifying the adsorption parameters of several organic compounds from the aqueous environment [29].

\begin{tabular}{|l|l|}
\hline \multicolumn{2}{|c|}{ Properties } \\
\hline Molecular weight & $315.58 \mathrm{~g} \cdot \mathrm{mol}^{-1}$ \\
\hline Density & $1.53 \mathrm{~g} / \mathrm{cm}^{3}$ \\
\hline Melting point & $254-256^{\circ} \mathrm{C} ; 489-493^{\circ} \mathrm{F} ; 527-529 \mathrm{~K}$ \\
\hline Appearance & White powder \\
\hline Denomination & Trichlorocarbanilide, \\
& 3,4,4'-trichlorocarbanilide, \\
& 3-(4-Chlorophenyl)-1-(3,4-dichlorophenyl)urea \\
& TCC, Solubacter \\
\hline
\end{tabular}

Table 1

PHYSICAL AND CHEMICAL PROPERTIES OF TRICLORCARBAN (TCC)

\footnotetext{
*email: georgeta.ratea@gmail.com; ac_ion@yahoo.com
} 
In this work, based on previous experience of our group on sorption of environmental contaminants on carbon based nanomaterials [30,31], the adsorption of triclocarban was investigated on pristine and irradiated MWCNTs, at two different temperatures, specific to cold and warm seasons, in aqueous synthetic samples at different $\mathrm{pH}$ values and for different concentrations of humic acid ( $\mathrm{HA})$ from natural organic matter. These matrices were chosen in order to understand the influence of the chemical composition of the natural aqueous systems where these nanomaterials might appear. The most commonly used models of the adsorption isotherms, Freundlich and Langmuir were selected to fit the experimental data. The effects of the TCC concentration, of the temperature and of the concentration of humic acid from natural organic matter were tested to study the impact of the environmental conditions over the sorption process.

\section{Experimental part}

\section{Materials and methods}

The adsorbents used in this study were MWCNTs pristine and irradiated. The nanotubes were provided from Baywatch Germany and the irradiation was done in the laboratory of RWTH Aachen, Germany, as described in [32]. Triclocarban (minimum purity $99 \%$ ) was from Fluka/SigmaAldrich Chemical, Germany. HPLC grade acetonitrile was purchased from VWR Chemicals, France. The preparation of the working solutions as well as the chromatographic method used to analyze the samples was described in [30].

Quantitative evaluation of the dispersion degree of pristine and irradiated MWCNTs in aqueous solutions

The dispersion degree of pristine and irradiated MWCNTS was spectrophotometric determined [31]. Briefly, standard stock solutions of $1 \mathrm{mg}$ of nanostructure was dispersed in $25 \mathrm{~mL}$ of ultrapure water, aqueous solutions of 10 and 50 $\mathrm{mg} / \mathrm{L}$ humic acid, respectively. The prepared solutions were introduced in a ultrasonic bath for $10 \mathrm{~min}$ at 5 and $25^{\circ} \mathrm{C}$. The absorbance was measured at $530 \mathrm{~nm}$, the value of the wavelength being chosen after scanning between 300$800 \mathrm{~nm}$ in $10 \mathrm{~mm}$ quartz cuvettes using a UV-Vis CINTRA 202 spectrophotometer. The concentration of the dispersed pristine and irradiated MWCNTS was determined by fitting the measured absorbance value from the spectrum in the aqueous sorption solution to the calibrated reference spectra.

\section{The adsorption study}

The adsorption experiments of TCC on pristine and irradiated MWCNTs were done at different levels of the TCC concentration, obtained by dilution with ultrapure water or with aqueous solutions of humic acid 10 or 50 $\mathrm{mg} / \mathrm{L}$, from a stock solution $10 \mathrm{mg} / \mathrm{L} \mathrm{TCC}$ in acetonitrile to $25 \mathrm{~mL}$ working solutions containing $0.1 \mathrm{mg}$ of pristine or irradiated MWCNTs. The solutions were maintained during the sorption experiments at constant temperature of 5 or $25^{\circ} \mathrm{C}$ and mechanically stirred for several hours. Each 30 min, $50 \mu \mathrm{L}$ from each sample were filtered on $0.45 \mu \mathrm{m}$ PTFE syringe filters and the TCC concentration was chromatographically analyzed. The chromatographic method used in all measurements was described in [30].

Several influences: the effect of contact time, the effect of the concentration of carbon nanomaterials and of TCC, the effect of the temperature and the influence of $p \mathrm{H}$ were studied.

The TCC adsorption capacity $(\mathrm{mg} / \mathrm{g})$ is calculated by:

$$
q=\frac{C_{0}-C_{x}}{m} \times V
$$

where, $\mathrm{q}(\mathrm{mg} / \mathrm{g})$ is the TCC adsorption capacity $\mathrm{C}_{0}(\mathrm{mg} / \mathrm{L})$ and $C_{x}(\mathrm{mg} / \mathrm{L})$ are the initial and equilibrium TCC concentrations in the solution, $\mathrm{V}(\mathrm{L})$ the solution volume, and $\mathrm{m}(\mathrm{g})$ the mass of adsorbent, respectively.

\section{Characterization of the nanosorbents}

BET specific surface areas and pore size distribution

The Brunauer-Emmet-Teller (BET) specific surface area of the samples was determined with a Quantachrome NOVA 2200e instrument. Before each measurement, the samples were degassed at $150^{\circ} \mathrm{C}$ in vacuum for $4 \mathrm{~h}$. The specific surface area was determined from the BET equation and the pore volume from the amount of gas adsorbed at $p / p_{0}=0.99$, as described in [33].

\section{Dispersion characterization using UV-VIS methods}

$0.01 \mathrm{~g} / \mathrm{L}$ of non-irradiated and irradiated MWCNTs in 25 $\mathrm{mL}$ volumes of mixtures of different ratios $\mathrm{CH}_{3} \mathrm{CN}: \mathrm{H}_{2} \mathrm{O}$ were prepared. All the dispersions were sonicated for $10 \mathrm{~min}$, centrifuged and then, the degree of dispersion was estimated based on the absorbance, measured with a GBC Scientific Equipment Pty. Ltd CINTRA 202 V 3749 UV-Vis spectrometer.

\section{Scanning electron microscopy (SEM)}

The non-irradiated and irradiated MWCNTS surfaces were studied by SEM, by distributing the nanoparticles in thin layers on conductive surfaces. The images were obtained by using a microscope SEM (Philips Quanta Inspect $F$ ) coupled with $X$ radiation source of $30 \mathrm{kV}$ and magnification $\times 2000$.

\section{Fourier Transformed Infrared spectrometry (FTIR)}

The spectra were done using a Spectrum GX, Perkin Elmer, USA spectrometer. The samples were scanned between $4000-400 \mathrm{~cm}^{-1}$ with a resolution of $4 \mathrm{~cm}^{-1}$.

\section{Zeta potential ( $\zeta)$}

The Zeta potential was obtained by using the electrophoretic mobility in the calculations based on Smoluchowsky model [34]. The electrokinetic measurements were done by using a ZetaSizer, Nano ZS, Malvern, on the aqueous solutions of the studied carbon nanomaterials in a range of $\mathrm{pH}$ form 4 to 10 . The Zeta potential was considered as an indication of the electrostatic stability of the particles.

\section{Results and discussions}

\section{Characterization of the nanosorbents}

BET

The textural characteristics of pristine and irradiated MWCNTs, such as: the specific surface, the pores volume and the pores diameter were determined by nitrogen adsorption at $273 \mathrm{~K}$. It was observed that the pores diameter of the irradiated MWCNTS was higher in comparison with that of the pristine ones, but the specific surface was smaller, suggesting that irradiated MWCNTs present pore constrictions, which hinder nitrogen adsorption (table 2).

The specific surface was calculated based on BET equation. The total volume of the pores was estimated based on the adsorbed amount of nitrogen at a ratio p/po $=0.99$. The distribution of the pores dimensions was calculated from the desorption branch of the isotherm by using the Barrett-J oyner-Halenda (BJ H) method [35]. 
Table 2

TEXTURAL CHARACTERISTICS OF THE STUDIED MWCNTS

\begin{tabular}{|l|c|c|c|}
\hline Nanomaterial & $\begin{array}{c}\text { Specific } \\
\text { surface, } \mathrm{m}^{2} / \mathrm{g}\end{array}$ & $\begin{array}{c}\text { Pore } \\
\text { volume, } \\
\mathrm{cm}^{3} / \mathrm{g}\end{array}$ & $\begin{array}{c}\text { Pore } \\
\text { diameter, } \\
\mathrm{nm}\end{array}$ \\
\hline $\begin{array}{l}\text { MWCNTs } \\
\text { pristine }\end{array}$ & 170.77 & 1.09 & 3.20 \\
\hline $\begin{array}{l}\text { MWCNTs } \\
\text { irradiated }\end{array}$ & 131.55 & 1.58 & 1.79 \\
\hline
\end{tabular}

UV-Vis

Determination of the degree of dispersion of the studied nanosorbents in aqueous solutions. There were prepared standard stock solutions of $1 \mathrm{mg} / 25 \mathrm{~mL}$ pristine and irradiated MWCNTs in ultrapure water, as presented in [31]. The working standard solutions containing $0.05,0.1,0.15$, 0.2 and $0.25 \mathrm{mg}$ MWCNTs/25mL ultrapure water were prepared by corresponding dilution of the standard stock solution. The values of the absorbances of the prepared solutions were measured at the wavelength of $530 \mathrm{~nm}$ for both pristine and irradiated MWCNTs, by using a UV-Vis CINTRA 202 spectrophotometer and the calibration curves were determined (fig. 2).
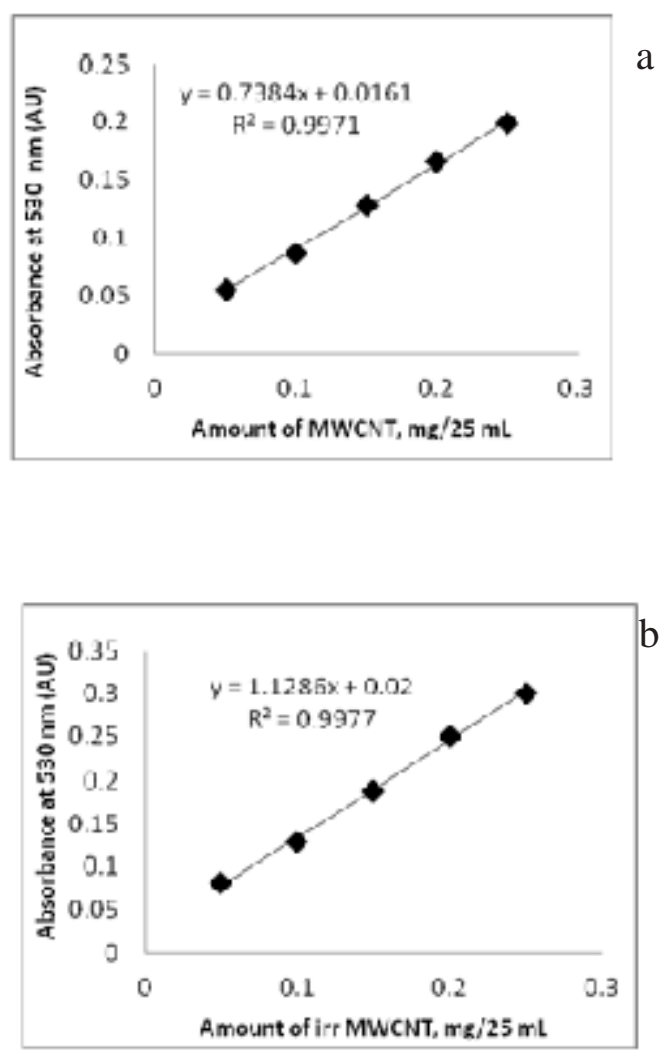

Fig. 2 The calibration curves of the aqueous suspensions of the studied nanomaterials: (a) pristine MWCNTs si (b) irradiated MWCNTS
SEM

The morphologies of the MWCNTs, both pristine and irradiated, impregnated and not impregnated with TCC are presented in figure 3, observing that in comparison with pristine MWCNTS, with a homogeneous distribution of the tubes, the irradiated ones present fragments on the external walls of the nanotubes, whose provenience might be due to the oxygen containing functional groups from the structure of the irradiated MWCNTs.

FTIR

The spectra are presented in figures 4 a-d. In Figure $4 a$ and $4 \mathrm{~b}$, there are compared the spectra of MWCNTs pristine and irradiated and separately, that one of triclocarban TCC.

In figure 4 a the spectra of TCC impregnated MWCNTs pristine and irradiated are compared in water, being observed that TCC was absorbed based on the TCC specific stretching vibration peaks for $\mathrm{C}=0$ at $1671 \mathrm{~cm}^{-1}$, for $=\mathrm{NH}$ at $1558 \mathrm{~cm}^{-1}$, for $=\mathrm{CH}_{3}$ at $1452 \mathrm{~cm}^{-1}$, for $-\mathrm{C}$ (0) NH at 1050 $\mathrm{cm}^{-1}$ and for $=\mathrm{C}-\mathrm{Cl}$ at $823 \mathrm{~cm}^{-1}$. These absorption maxima were observed in the spectra of TCC (fig. 4b), too.

In figures $4 \mathrm{c}$ and $4 \mathrm{~d}$, the spectra of the impregnated nanostructures with TCC in in humic acid aqueous solutions of two different concentrations, 10 and $50 \mathrm{mg} \mathrm{L}^{-}$ ${ }^{1}$ are presented, being observed that TCC was absorbed, based on the stretching vibration peaks for the $=\mathrm{C}=\mathrm{O}$ bond at $1637 \mathrm{~cm}^{-1}$ and $1616 \mathrm{~cm}^{-1}$, for the $=\mathrm{C}=\mathrm{C}$ bond at $1384 \mathrm{~cm}^{-1}$, for the $=\mathrm{NH}$ bond la $1558 \mathrm{~cm}^{-1}$ and $1550 \mathrm{~cm}^{-1}$, for $-\mathrm{C}(0) \mathrm{NH}$ at $1127 \mathrm{~cm}^{-1}$, for $-\mathrm{C}=\mathrm{CH}_{2}$ at $1051 \mathrm{~cm}^{-1}$ and for $=\mathrm{C}-\mathrm{Cl}$ at $823 \mathrm{~cm}^{-1}$.

Zeta potential $(\zeta)$ of the pristine and irradiated MWCNTS was measured in the $\mathrm{pH}$ range between 4 and 10 (table 3), being observed that:

- pristine MWCNTs at acidic pH values of the aqueous solution present unstable colloids, positively charged. By increasing the $\mathrm{pH}$ values, the colloids have negatively charges and become more stable till values of the $\mathrm{pH}$ of 10 or 11 .

- the irradiated MWCNTs are colloidally unstable atacidic values of the $\mathrm{pH}$, the positive charge influencing the aggregation tendency. By increasing the $\mathrm{pH}$, the colloids become negatively charged and the systems colloidally stable.

As it can be observed from table 3, for the samples containing pristine MWCNTs, at acidic $\mathrm{pH}$, positively charged less stable colloids are forming, which by increasing the $\mathrm{pH}$ values become negatively charged and more stable. For the samples containing irradiated MWCNTs at acidic $p H$ values, unstable positively charged colloids are forming, an increased tendency of aggregation being observed at $p H=5$. By increasing the $p \mathrm{H}$ at more basic values, the colloids become negatively charged and stable. Based on these results, the working $\mathrm{pH}$ in the sorption experiments was chosen and measured [36] between 7 and 9 , in this range the overall surface of both types of nanostructures being negatively charged.
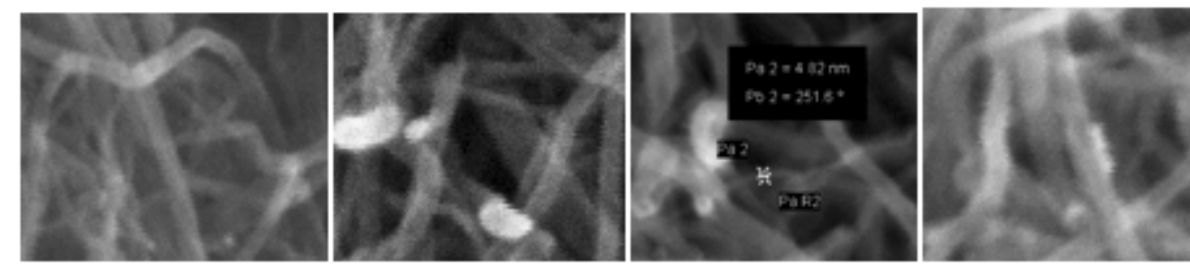

Fig. 3 SEM micrographies of the pristine and irradiated MWCNTs, before and after TCC sorption: a-pristine MWCNTS without TCC; b- MWCNTs pristine with TCC; $c$ - irradiated MWCNTs without TCC; $d$ - irradiated MWCNTs with TCC 


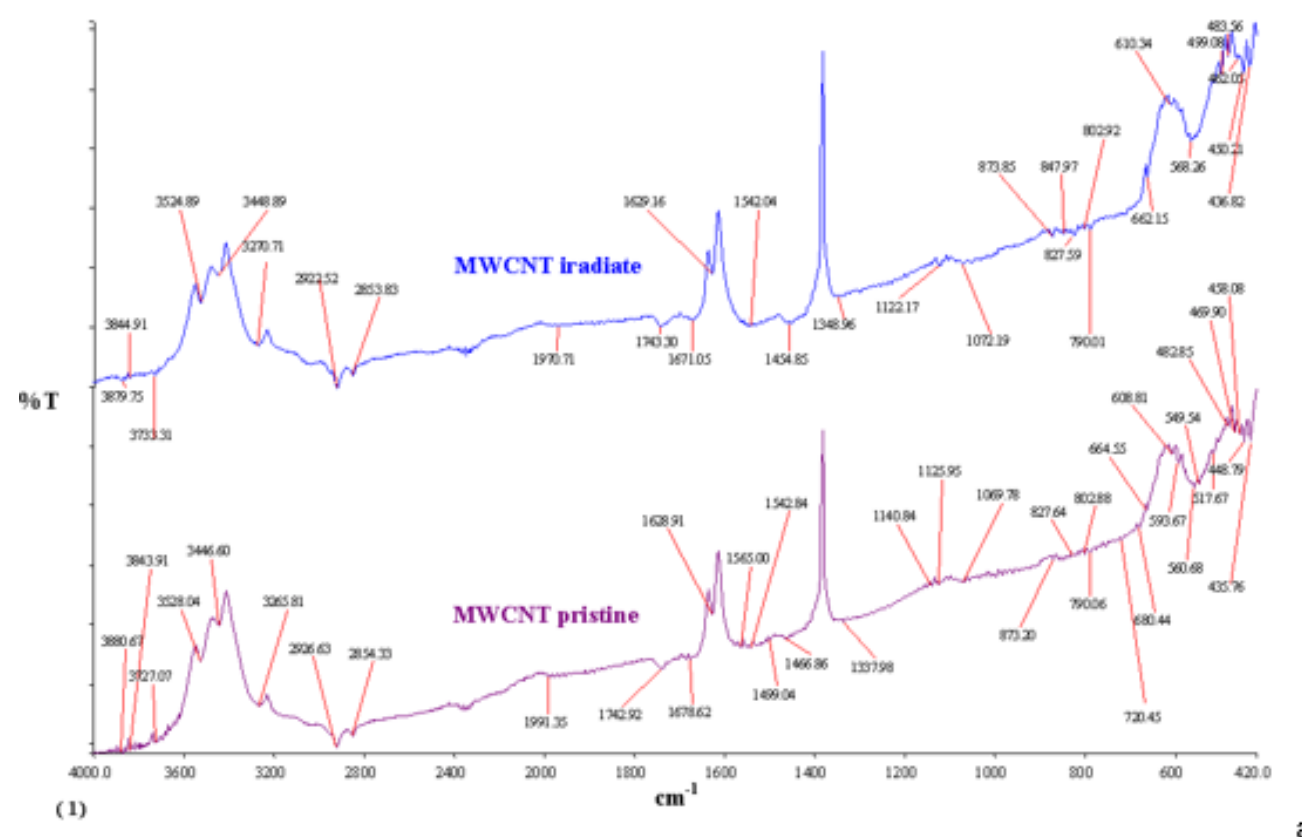

a

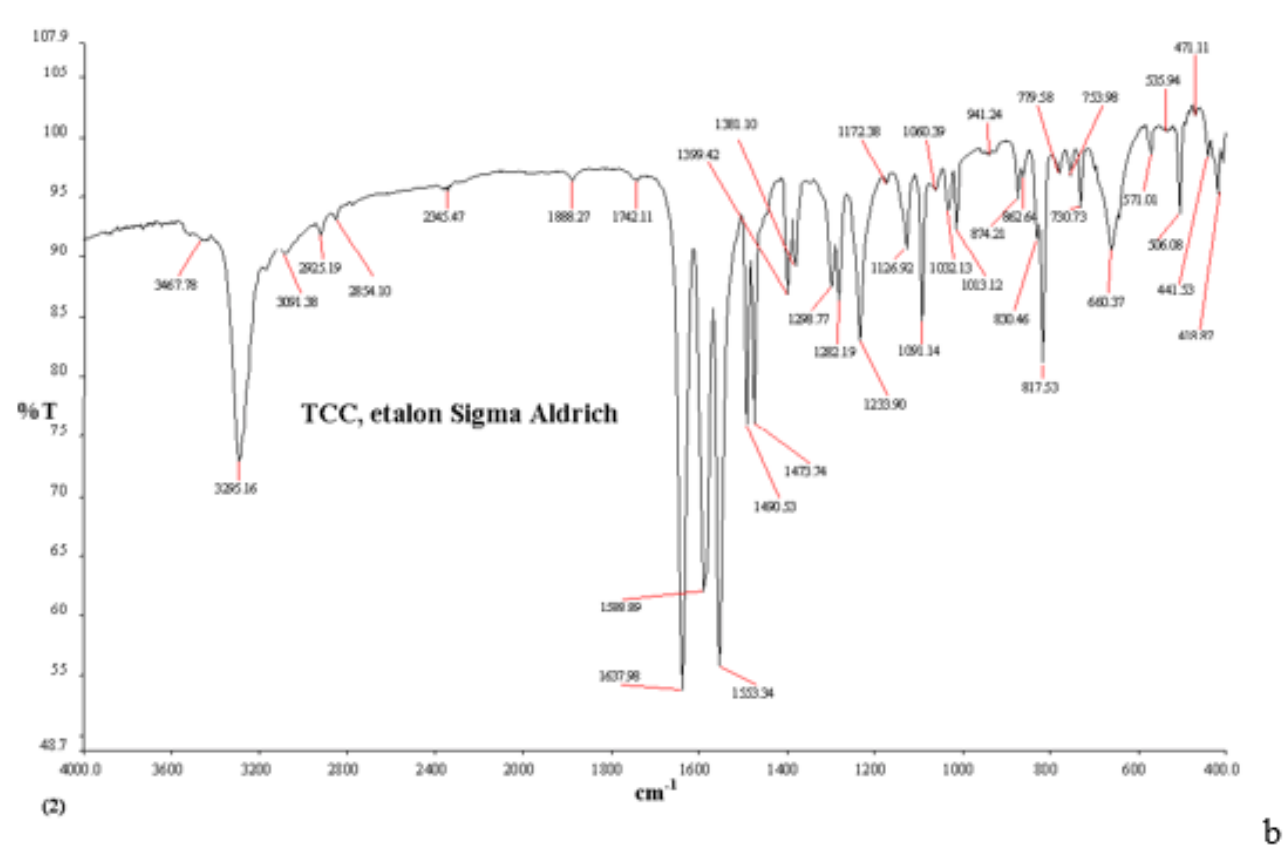

Fig.4 (a-c) FTIR spectra of pristine and irradiated MWCNTs before and after the sorption of TCC

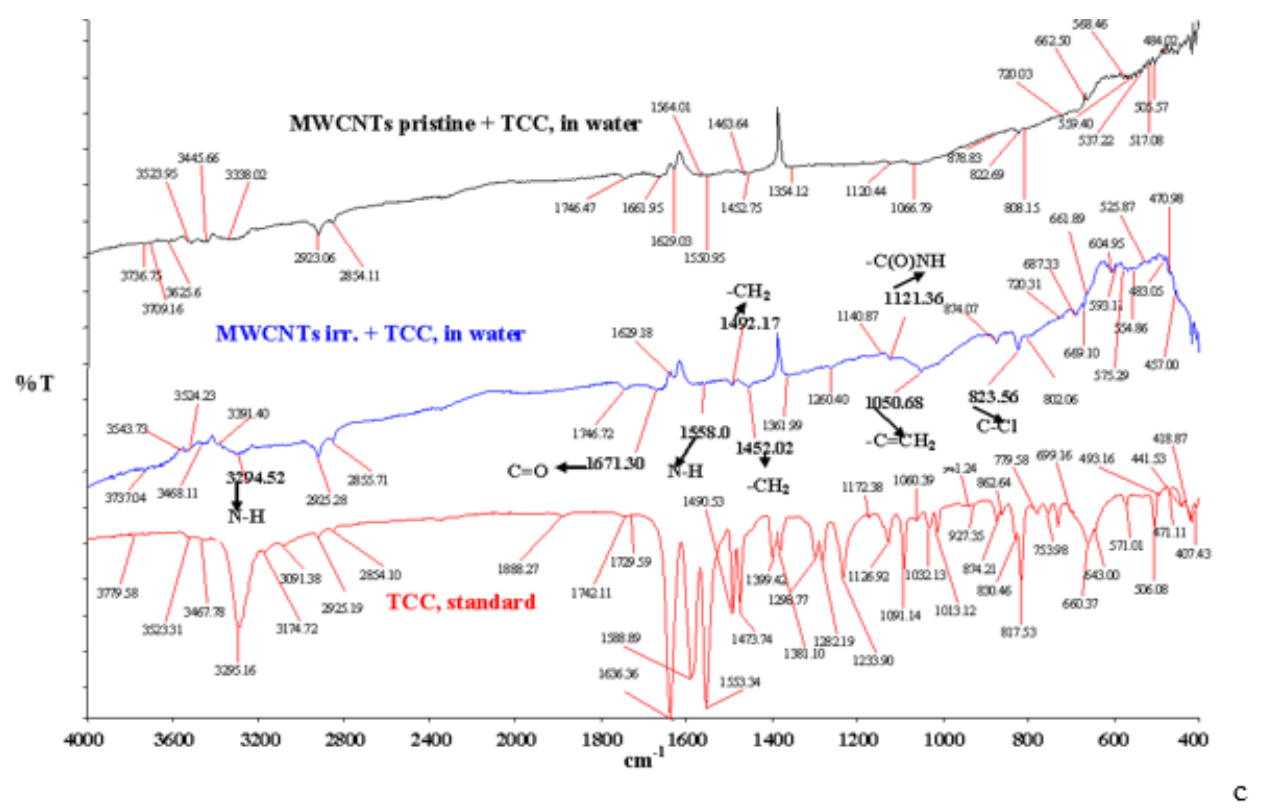




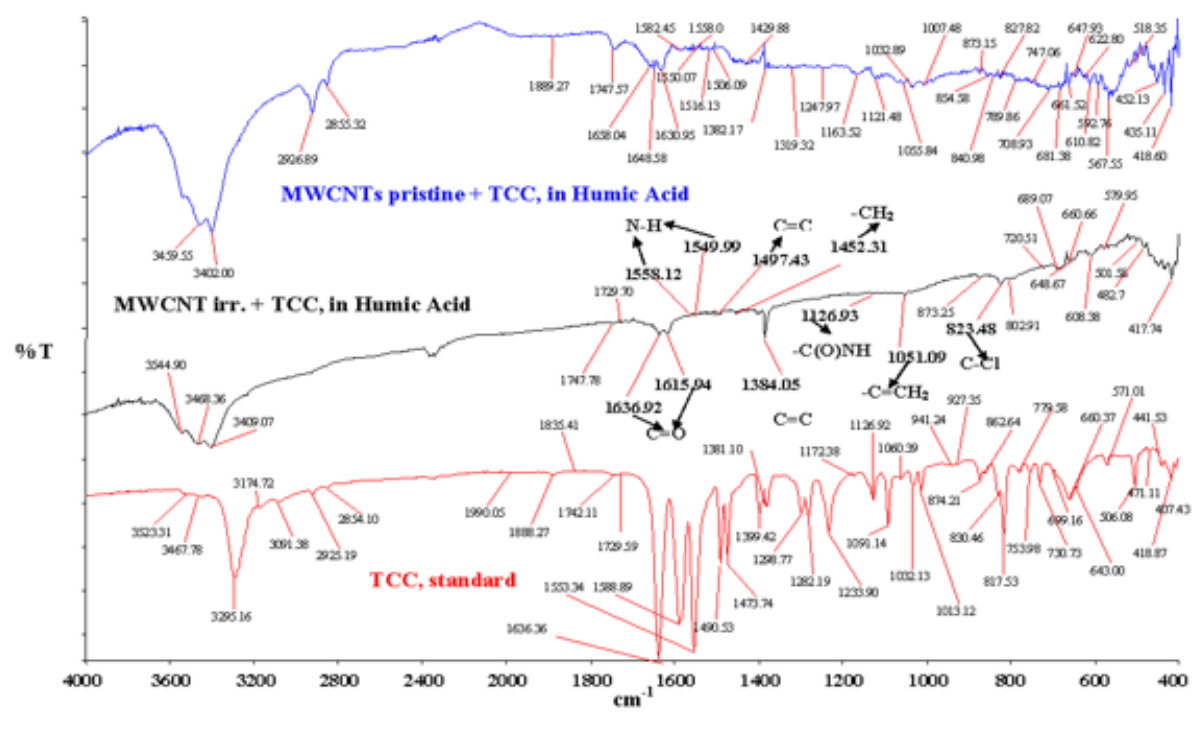

Fig.4 (d) FTIR spectra of pristine and irradiated MWCNTs before and after the sorption of TCC

Table 3

VALUES OF THE ZETA POTENTIAL FOR PRISTINE AND IRRADIATED MW CNTS IN THE PH RANGE of 4-10

\begin{tabular}{|c|c|c|}
\hline \multirow{2}{*}{$\mathbf{p H}$} & \multicolumn{2}{|c|}{ Zeta Potential, mV } \\
\cline { 2 - 3 } & $\begin{array}{c}\text { Pristine } \\
\text { MWCNTS }\end{array}$ & $\begin{array}{c}\text { Irradiated } \\
\text { MWCNTs }\end{array}$ \\
\hline 4 & 38.1 & 16.3 \\
\hline 5 & -26.3 & 8.33 \\
\hline 7 & -36.6 & -29.3 \\
\hline 9 & -33.5 & -35.5 \\
\hline 10 & -31.0 & -33.9 \\
\hline
\end{tabular}

Sorption isotherms of TCC on pristine and irradiated MWCNTS

The Langmuir and Freundlich adsorption isotherm models were adopted for describing the sorption of TCC on pristine and irradiated MWCNTs at equilibrium, in ultrapure water and in humic acid aqueous solutions, mimicking their concentrations found in natural waters [37]. The interrupted lines represent the fitting with indicated models equations and the dots the obtained experimental values at the studied temperatures of 5 and $25^{\circ} \mathrm{C}$. The values of the sorption parameters were calculated from the two applied models, Freundlich and Langmuir at the studied temperatures and there are presented in table 4.

\begin{tabular}{|c|c|c|c|c|c|c|}
\hline \multirow{2}{*}{$\begin{array}{l}\text { Sorption conditions } \\
\text { at } 25^{\circ} \mathrm{C}\end{array}$} & \multicolumn{3}{|c|}{ Langmuir } & \multicolumn{3}{|c|}{ Freundlich } \\
\hline & $\overline{\mathrm{K}_{\mathrm{L}}, \mathrm{L} / \mathrm{mg}}$ & $q_{m}, \mathrm{mg} / \mathrm{g}$ & $\mathrm{R}^{2}$ & $\mathrm{~K}_{\bar{z}}$ & $\mathrm{n}$ & $\mathrm{R}^{2}$ \\
\hline MWCNT pristine in water & 0.0713 & 59.71 & 0.9891 & 9.08 & 0.4557 & 0.9756 \\
\hline $\begin{array}{l}\text { MWCNT pristine in } 10 \mathrm{mg} / \mathrm{L} \\
\mathrm{HA}\end{array}$ & 0.0494 & 61.06 & 0.9875 & 6.86 & 0.4662 & 0.9167 \\
\hline $\begin{array}{c}\text { MWCNT pristine in } 50 \mathrm{mg} / \mathrm{L} \\
\mathrm{HA}\end{array}$ & 0.0217 & 64.68 & 0.9330 & 3.20 & 0.5917 & 0.9791 \\
\hline MWCNT irradiated in water & 0.0365 & 39.97 & 0.9655 & 12.24 & 0.3325 & 0.9620 \\
\hline $\begin{array}{c}\text { MWCNT irradiated in } 10 \\
\mathrm{mg} / \mathrm{L} \mathrm{HA}\end{array}$ & 0.0530 & 42.21 & 0.8971 & 5.93 & 0.4267 & 0.9740 \\
\hline $\begin{array}{c}\text { MWCNT irradiated in } 50 \\
\mathrm{mg} / \mathrm{L} \mathrm{HA}\end{array}$ & 0.0692 & 49.13 & 0.9876 & 6.08 & 0.4959 & 0.9790 \\
\hline
\end{tabular}

\begin{tabular}{|c|c|c|c|c|c|c|}
\hline \multirow{2}{*}{$\begin{array}{l}\text { Sorption conditions } \\
\text { at } 5^{\circ} \mathrm{C}\end{array}$} & \multicolumn{3}{|c|}{ Langmuir } & \multicolumn{3}{|c|}{ Freundlich } \\
\hline & $\mathrm{K}_{\mathrm{L}, \mathrm{L} / \mathrm{mg}}$ & $\mathrm{q}_{\mathrm{m}, \mathrm{mg} / \mathrm{g}}$ & $\mathrm{R}^{2}$ & $\mathrm{~K}_{\bar{z}}$ & $\mathrm{n}$ & $\mathrm{R}^{2}$ \\
\hline MWCNT pristine in water & 0.7311 & 24.05 & 0.9631 & 9.98 & 0.5053 & 0.9310 \\
\hline $\begin{array}{c}\text { MWCNT pristine in } 10 \mathrm{mg} / \mathrm{L} \\
\text { HA }\end{array}$ & 0.6050 & 35.30 & 0.9273 & 12.94 & 0.3595 & 0.9361 \\
\hline $\begin{array}{c}\text { MWCNT pristine in } 50 \mathrm{mg} / \mathrm{L} \\
\mathrm{HA}\end{array}$ & 0.1481 & 49.14 & 0.8142 & 8.09 & 0.5521 & 0.9611 \\
\hline MWCNT irradiated in water & 0.1378 & 34.49 & 0.9434 & 8.64 & 0.3261 & 0.9255 \\
\hline $\begin{array}{c}\text { MWCNT irradiated in } 10 \\
\mathrm{mg} / \mathrm{L} \mathrm{HA}\end{array}$ & 0.0214 & 35.84 & 0.9640 & 3.13 & 0.4416 & 0.9289 \\
\hline $\begin{array}{c}\text { MWCNT irradiated in } 50 \\
\mathrm{mg} / \mathrm{L} \mathrm{HA}\end{array}$ & 0.1057 & 26.54 & 0.9755 & 4.29 & 0.2892 & 0.9629 \\
\hline
\end{tabular}

Table 4

FITTING PARAMETERS OF FREUNDLICH AND LANGMUIR MODELS FOR THE TCC SORPTION ON THE STUDIED NANOMATERIALS, IRRADIATED MWCNTS AT 5 AND $25^{\circ} \mathrm{C}$ 

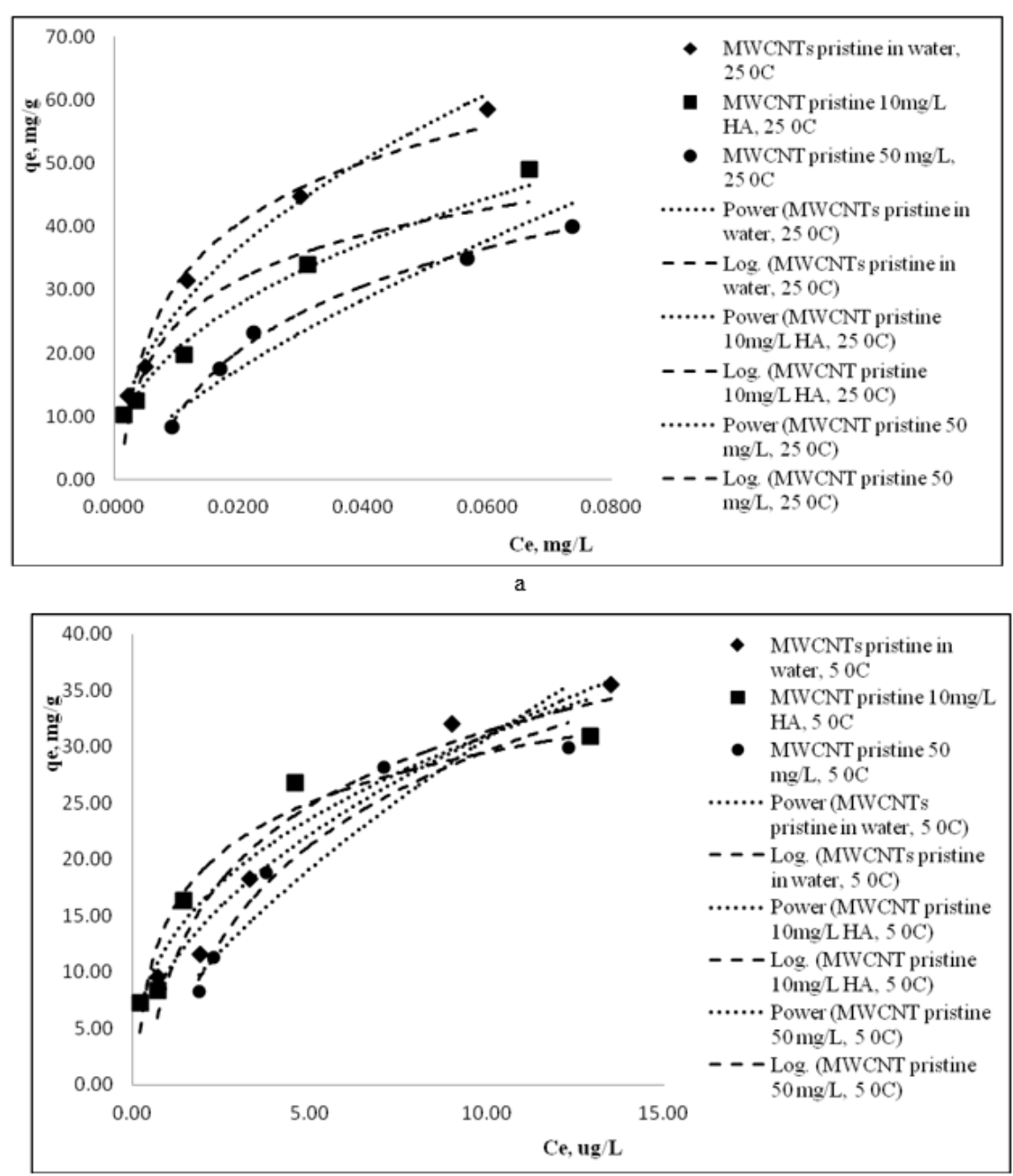

Fig. 5 The adsorption isotherms of TCC on pristine MWCNTs in ultrapure water and in humic acid at $25(\mathrm{a})$ and $5^{\circ} \mathrm{C}(\mathrm{b})$
It can be observed trom tigure $s$ that both models titted well with the experimental data. There might be three types of adsorption sites present on the pristine MWCNTs: external surfaces, interstitial channel and grooves [38]. Usually for MWCNTs, the external surfaces present the most important adsorption sites [39], so both derived Langmuir and Freundlich models fit with the experimental data at the studied temperatures. It was observed that at 5 ${ }^{\circ} \mathrm{C}$, both models present smaller values of the correlation coefficients, probably in connection with the lower solubility of TCC in aqueous solutions at lower temperatures.

It can be observed from figure 6 that the adsorption capacities of TCC decrease on irradiated MWCNTs in comparison with pristine ones. This is in accordance with other results from the literature [40]. A possible explanation might be that the specific surface area of irradiated MWCNTs is reduced by irradiation, caused by its partial cover with oxygen containing groups [41]. The hydrophobicityplays also an important role in the adsorption of the trichlorinated aromatic compound TCC.

From table 4 , by the comparison of the parameters values obtained by fitting with the Langmuir and Freundlich sorption models, it can be concluded that both models offer better values at higher temperature $\left(25^{\circ} \mathrm{C}\right)$ and both fit better with the experimental values at this temperature. The Langmuir model works with the premises that the adsorption is caused by chemical forces; the adsorbed film is a monolayer and all the adsorption sites are energetically equivalent, no interactions taking place between the adsorbed molecules.
The Freundlich model fitalso with the experimental data, presenting values of the non-linearity index $n$ between 0.2892 and 0.5917 , being known that for unity values of $n$, the non-linearity if the sorption systems decrease. The factors already reported to influence the non-linearity are the molar volume of adsorbate and the electrostatic repulsions between the sorbent and the adsorbed molecules [42].

\section{Proposed sorption mechanism of TCC on simple and irradiated MWCNTS}

The proposed sorption mechanism of TCC on simple and irradiated MWCNTs is presented in figure 7.The adsorption capacity of TCC on pristine and irradiated MWCNTs was observed to be higher on the pristine ones. It was also already mentioned in the literature that the imcrease of the number of oxygen-containing functional groups on the surface of the nanostructures decrease their adsorption capacity over hydrophobic contaminants [43]. It is possible that the oxygen-containing functional groups to form polar regions that favor the formation of water clusters on the adsorption sites, these ones inhibiting the the adsorption of TCC molecules [44]. It was already observed that the specific surface area of the MWCNTS are reduced by oxidation and that the oxides on the surfaces of MWCNTs decrease the electron-donor character of MWCNTs. As a result, the EDA interactions are reduced and this decreases the adsorption capacity of the irradiated MWCNTS. 

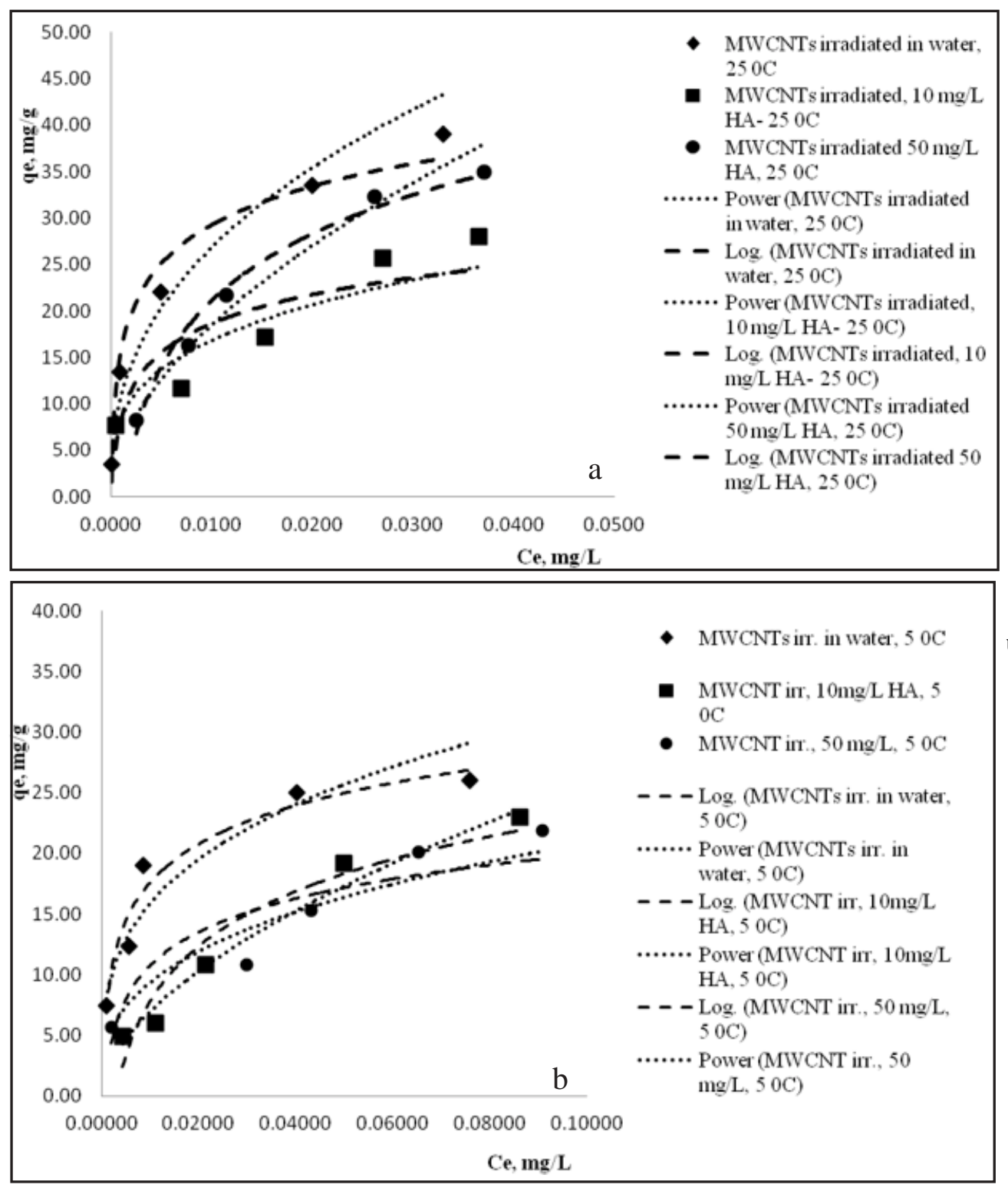

Fig. 6 Adsorption isotherms of TCC on irradiated MWCNTs in ultrapure water and in humic acid at 25 (a) and $5{ }^{\circ} \mathrm{C}(\mathrm{b})$

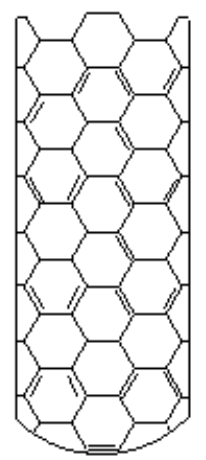

MWCNT s

\section{Conclusions}

This study adds to the other studies from the literature, an improved application of MWCNTs as sorbents for hydrophobic organic contaminants. The adsorption equilibrium of the studied organic contaminant TCC was reached in $30 \mathrm{~min}$, the kinetics being better described by a pseudo-second order model. All the adsorption isotherms fitted well with Langmuir and Freundlich models, beeing observed that the adsorption capacity decreases on irradiated MWCNTs in comparison with pristine ones. It seems that the hydrophobicity of the studied organic<smiles>O=C(Nc1ccc(Cl)cc1)Nc1ccc(Cl)cc1</smiles>

Fig. 7 Sorption mechanism of TCC on simple and irradiated MWCNTs 
Acknowledgments: This research was performed in the frame of ERA-NET SIINN, funded by the European Commission within the 7th Framework Program and supported by the Romanian Executive Agency for Higher Education and RDI Funding (Unitatea Executiva pentru Finantarea Invatamantului Superior, Cercetarii, Dezvoltarii si Inovarii: UEFISCDI).

\section{References}

1.PALMIOTTO,M., CASTIGLIONI, S., ZUCCATO, E., MANENTI,A., RIVA, F, DAVOLI, E., J. Environ. Management, 214, 2018, p. 76. 2.DING, S.L., WANG,X.K., JIANG, W.Q., ZHAO,R.S., SHEN, T.T., WANG, C., WANG, X., Environ. Sci. Pollut. Res., 22, 2015, p. 52014. 3.SAPKOTA, A., HEIDLER, J., HALDEN, R.U., Environ. Res., 103, 2007, p, 21.

4.HYNTHER, A., BROMBA, C.M., WULFF, J.E., HELBING, C.C. Environ. Sci. Technol., 45, 2011, p. 5395.

5.ZARATE, F.M., SCHULWITZ, S.E., STEVENS, K.J., VENABLES, B.J ., Chemosphere, 88, 2012, p. 323.

6.SCHEBB, N.H., INCEOGLU, B., MORISSEAU, C., AHN, K.C., GEE, S.J . HAMMOCK, B.D., Environ. Sci. Technol., 45, 2011, p. 3109.

7HODGES SNYDER, E., O'CONNOR, G.A., MCAVOY, D.A., Sci. Total Environ., 408, 2010, p. 2667.

8.HALDEN, R.U., PAULL, D.H., Environ Sci. Technol, 38, 2004, p. 4849.

9.CHALEW, T.E., HALDEN, R.U., J Am Water Works Assoc., 45, nr.1, 2009, p. 4.

10.HODGES SNYDER, E., O'CONNOR, G.A., MCAVOY, D.C., Chemosphere, 82, 2011, p. 460

11.*** INERIS, 2016. Données technico-économiques sur les substances chimiques en France: Triclocarban, DRC-16-158744-08924A, 32p, www.ineris.fr/substances/fr/.

12.ROMAN, D., BARNETT, E., BALSKE, R., Toilet Good Assoc., 28, 1957, p. 12

13. *** https://en.wikipedia.org/wiki/Triclocarban.

14. *** TCC Consortium IUCLID data set, report 201-14186 B, 2009.

15.YING, G., YU, X., R. KOOKANA, Environ. Pollut,150, 2007, p. 300. 16.SNYDER, E.H., O'CONNOR, G.A., Sci. Total Environ., 442, 2013, p. 437.

17.HALDEN R.U., PAULL, D.H., Water ResourcesEnviron. Sci. Technol., 39, 2005, p. 1420.

18.HEIDLER, J., SAPKOTA, A., HALDEN, R., Environ. Sci. Technol., 40, 2006, p. 3634.

19.*** USEPA Targeted national sewage sludge survey sampling and analysis technical report Technical reportEPA-822-R-08-016 Washington DC; USEPA 2009b.

20.SADEGH, H., GHOSHEKANDI, R.S., MASJEDI, A., MAHMOODI, Z., KAZEMI, M., Int. J. Nano Dimens.,7, no. 2, 2016, p. 109.
21.DIL, E.A., GHAEDI, M., ASFARAM, A., Ultrasonic Chem., 34, 2017, p. 792.

22.MAUTER, M.S., ELIMELECH, M., Environ. Sci. Technol., vol. 42, no. 16,2008, p. 5843.

23. ALI, I., Chem. Rev., 112, no.10, 2012, p. 5073.

24.WANG, S., SUN, H., ANG, H.M., TADE, M,, Chem. Eng. J ., 226, 2013, p. 336.

25.LIU, X., WANG, M., ZHANG, S., PAN, B., J. Environ. Sci., 25, no. 7, 2013, p. 1263.

26.SHI, B., ZHUANG, X., YAN, X., LU, J., J. Environ. Sci., 22, no. 8, 2010, p. 1195.

27.ZHAO, H., LIU, X., CAO, Z., ZHAN, Y., SHI, X., YANG, Y., ZHOU, J., J. Hazard. Mat., 310, 2016, p. 235.

28.KUSMIEREK, K., SWIATKOWSKI, A., Desalin. Water Treatment, 2014, p. 1.

29.DING, H., LI, X., WANG, J., ZHANG, X., CHEN, C., J. Environ. Sci., 43, 2016, p. 187.

30.I. ION, G.R. IVAN, R.M. SENIN, S.M. DONCEA, L. CAPRA, O. OPREA, G. STINGA, A.C. ION, Sep. Sci. Technol., 2019, doi:10.1080/ 1496395.2019.1577450.

31. SENIN, R.M., ION, I., ION, A.C., Polish J. Environ. Studies, 27, no. 5, 2018, p. 1.

32.SENIN, R.M., ION, I., OPREA, O., STOICA, R., GANEA, R., ION, A.C., Rev. Chim. (Bucharest), 69, no. 6, 2018 p. 1233.

33.SENIN, R.M., ION, I., VASILE, B., STOICA, R., GANEA, R., ION, A.C., Rev. Chim. (Bucharest), 69, no. 5, 2018, p. 1310.

34. KHARE, N., BAJ PAI, J., BAJ PAl, A.K., Environ. Nanotech., Monitoring and Management, 10, 2018, p. 148.

35.ZHAO, J., WANG, Z., GHOSH, S., XING,B., Environ.Pollut. 184, 2014, p. 145.

36.A. C. ION, I. ION, M.M.G. ANTONISSE, D.N. REINHOUDT, Russian J. General Chem. 71(2), 2001, p. 159

37.GOTOVAC, S., HATTORI, Y., NOGOGUCHI, D., MIYAMOTO, J., KANAMARU, M., UTSUMI, S., KANOH, H., KANEKO, K., J. Phys. Chem. B, 110, no. 33, 2006, p. 16219.

38.REN, X., CHEN, C., NAGATSU, M., Chem. Eng. J .,170, no. 2-3, 2011, p. 395-410.

39.PAN,B., XING, B., Sci. Technol. 42, no. 24, 2008, p. 9005.

40.YU, F., MA, J., HAN, S., Sci. Rep.,4, 2014.

41.SHENG, D.G., REN, D.D., REN, M.X., WANG, Q.X., LI, X.J ., CHEN, X.Y., WANG, K.X., J. Hazard. Mater., 178, no.(1-3), 2010, p. 505.

42.SUN, K., ZHANG, Y.Z., GAO, B., WANG, Y.Z., XU, Y.D., JIN, J., LIU, T.X., Sci. Total Environ., 439, 2012, p. 1.

43.ZHOU, S., SHAO, Y., GAO, N., DENG, J., TAN, C., Clean Soil, Air, Water, 41, no. 6, 2013, p. 539-547.

44. MA, X., ANAND, D., ZHANG, X., TALAPATRA, S., J. Phys. Chem. C, 115, no. 11, 2011, p. 4552.

$\overline{\text { Manuscript received: } 25.06 .2018}$ 